\title{
AIRPORT LOCATION OF CITY CENTER AND ITS CONTRIBUTION TO AIR QUALITY
}

\author{
Ervina AHYUDANARI ${ }^{1}$
}

DOI: $10.21163 / \mathrm{GT} \_2019.141 .31$

\begin{abstract}
:
The contribution of aircraft to the environment is comprised of three stages. First is to the surrounded airport, second to the area of the aircraft climbing path, and third is to the flight level during cruising. The first and the second stages of aircraft contribute to the air quality of urban area next to the airport. Emission in cruising level brings impact on greenhouse gases. To investigate the effect of the location of the airport in contributing the urban air quality, characteristics of aircraft movements are required. The identification of the characteristics of aircraft movements envelopes the flight path from the runway to airborne. The emission of the jet engines of the aircraft is estimated. The emission estimated is then compared to the emission measured in the surrounded airport. The estimation of emission dispersion along the flight path is determined based on the aircraft types and the height of the flight path from the ground. The contribution of the aircraft movements to the air quality can be calculated. The analysis shows that the location of the airport causes emission accumulation due to the climbing process of the aircraft.
\end{abstract}

Key-words: Aircraft Movements, GHG Emissions, Flight Path, Urban Air Quality.

\section{INTRODUCTION}

Air transport is an important component of economic growth. Increased demand for air transport shows the economic development of an area. The ever-increasing demand makes the growth of competitive airlines with low-cost carriers. Besides the positive side, the aviation industry also contributes to the negative side. The number of aircraft movements would have an impact on environmental problems. The problem of the impact of aircraft movement at the airport is of particular concern to the aviation world. The impacts caused by aircraft movement are noise pollution problems, air pollution problems, land use and hydrological and ecological problems for the area around the airport.

The increasing demand for air transport will also result in the magnitude of the impacts caused by aircraft movements in the airport environment. Since the beginning of the era of jet-engines commercial airplanes in 1959, there has been a dramatic change in airport noise problems in form and magnitude. The noise became the most difficult problem to be controlled so this noise gave rise to the Federal Aviation Administration (FAA) Regulations Part 36 in 1969 on noise standards for the new design certification of turbojet-engine aircraft (FAA, 2017). Regulations on environmental impacts are also regulated in the International Civil Aviation Organization (ICAO), Annex 16 Environmental Protection (ICAO, 2004).

In addition to noise issues, the operation of the aircraft produces pollutants in the engine exhaust gases. Engine exhaust gases or emissions have a negative impact on airport environmental quality. Aircraft emissions have two main components, carbon dioxide, and

\footnotetext{
${ }^{1}$ Institut Teknologi Sepuluh Nopember, Department of Civil Engineering, Kampus ITS Sukolilo, Surabaya60111, Indonesia, ervina@ce.its.ac.id
} 
water vapor. At the time of the runway phase of the aircraft, the movement is landing or take off. At this phase of the aircraft emissions that directly impact the airport environment.

Air travel demand is expected to grow by $77 \%$ over the next twenty years, indicating high emissions in the airport environment and special needs are needed to address the impact of the airport for local people (Rissman et al., 2013). Regarding emission issues according to Masiol \& Harrison (2015) among other emission sources, the major emission contributor to the London area comes from Heathrow Airport, London.

Seeing the problem of the impact of aircraft movement in airport environments, through the review of this journal is expected to know the problems of aircraft movement impact on air pollution and control that can be done.

\section{AIRCRAFT EMISSION}

Air pollution is a condition in which the air around this is polluted by negative chemicals, substances or particles, or other biological substances that are harmful to humans and other living things. Air pollution generated by the aircraft needs to be taken into account the adverse effects on the environment. Although air pollution caused by aircraft only accounts for a small percentage of the total world pollution, with the higher commercial flight frequency will have an impact on the percentage increase.

The aircraft uses aviation fuel which is fuel sourced from fossils. The source of energy is a source of energy that cannot be compromised. Excessive use of fossil fuels will certainly cause problems for the environment. When fossil fuel is burned it releases Carbon dioxide $\left(\mathrm{CO}_{2}\right)$. Exhaust gases other than $\mathrm{CO}_{2}$, form Nitrous Oxide $\left(\mathrm{NO}_{\mathrm{x}}\right)$, Volatile Organic Compound (VOC), Carbon Monoxide (CO), Sulfur Dioxide $\left(\mathrm{SO}_{2}\right)$. The emission content is certainly harmful to human health and the environment (Rypdal, 2002)

The aircraft produces emission from start engine to turn off the engine. During flight operations, there are several phase stages as shown in Fig. 1. Each phase produces a different amount of emission due to the combustion process in the jet engines. The emission dispersion to the atmosphere depends on the altitude of the flight level as the temperature at each altitude is different.

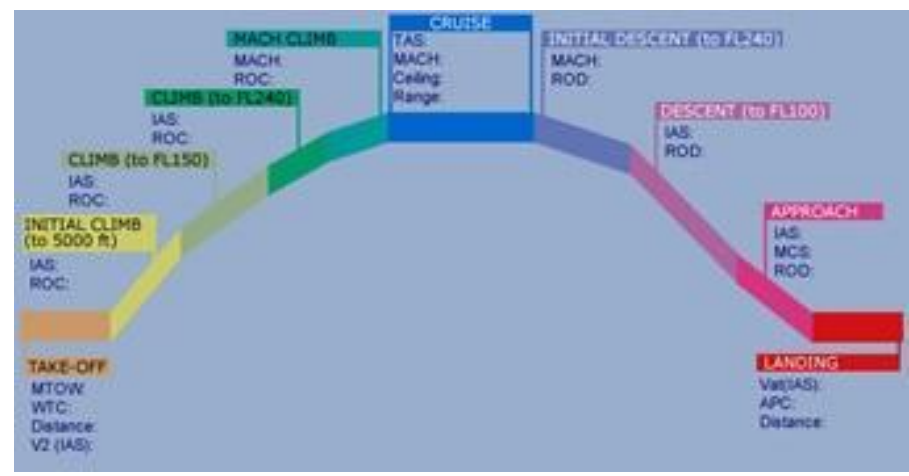

Fig. 1. Aircraft Movement Phases (Eurocontrol, 2016).

Aircraft phases that require special attention due to pollution at the airport are during taxi, take off, climb out (fly up from take-off to $914.4 \mathrm{~m}$ altitude), approach and landing. For most jet-powered aircraft, the rate of pollutant emissions of carbon monoxide and 
hydrocarbons occurs when the aircraft is a taxi and the largest nitrogen oxides emissions occur when the aircraft takes off.

Research on the contribution of commercial aircraft emissions to the take-off phase by Song \& Shon (2012) shows that the operational emissions of take-off phase aircraft contribute high. In addition to the airport environment that has been described, the contribution of aircraft emissions also continues in the air space. When the plane is at an altitude above $16 \mathrm{~km}$, nitrogen oxide through the photocatalytic process can trigger ozone layer damage. This is reinforced by the atmospheric experts who joined in the World Wide Fund (WWF) environmental agency in 1991 said that the main suspect of the widening ozone hole is $\mathrm{NO}_{\mathrm{x}}$ pollution from the air transport system. $\mathrm{NO}_{\mathrm{x}}$ emissions contribute to global warming by $5 \%$ to $40 \%$. This happens because $\mathrm{NO}_{\mathrm{x}}$ can chemically break down ozone with the help of sun's ultraviolet rays.

In 1999, the Intergovernmental Panel on Climate Change (IPCC) issued a report and among the most important points about aviation as follows:

i) The airplane produces $2 \%$ of the total production of carbon dioxide $\left(\mathrm{CO}_{2}\right)$ emissions $\mathrm{yr}^{-1}$ or as much as $13 \%$ of the $\mathrm{CO}_{2}$ emissions generated from all vehicles. Projected to rise to $3 \%$ by 2050 . The report also notes that $\mathrm{CO}_{2}$ remains in the atmosphere for at least 100 years so the effect is cumulative.

ii) Emissions from Nitrogen Oxide $\left(\mathrm{NO}_{\mathrm{x}}\right)$ from subsonic aircraft are predicted to increase by $6 \%$ since 1992 . So projected to rise to $13 \%$ by 2050 .

Contrast traces of exhaust produce water vapor $\left(\mathrm{H}_{2} \mathrm{O}\right.$ and Hydrocarbon) have covered about $0.1 \%$ of the Earth's surface since 1992. It is estimated to increase by at least $0.5 \%$ by 2050. This smoke trail can survive in the atmosphere and directly affect the effects of the greenhouse. In addition, smoke traces contribute to an increase in the occurrence of cirrus clouds that can cover about $30 \%$ of the earth's surface.

\subsection{Measurement of Aircraft Emission}

Research on the measurement of aircraft emission has been attempted from a different approach. Romano et al. (1999) presented various methods to estimate the emission produced by different aircraft. The methods presented in Table 1.

Table 1. Input data required by the different methodologies.

\begin{tabular}{|l|c|c|c|c|c|}
\hline \multirow{2}{*}{ Input Data } & \multicolumn{5}{|c|}{ Methodology } \\
\cline { 2 - 6 } & Very Simple & Simple & $\begin{array}{c}\text { Alternative } \\
\text { Simple }\end{array}$ & Detailed & $\begin{array}{c}\text { Very } \\
\text { Detailed }\end{array}$ \\
\hline Fuel & Total & Total & Total & $\begin{array}{c}\text { Total } \\
\text { aircraft type }\end{array}$ \\
\hline No. flights & Total & $\begin{array}{c}\text { Total } \\
\text { aircraft type }\end{array}$ & Total & $\begin{array}{c}\text { Total } \\
\text { aircraft type }\end{array}$ & $\begin{array}{c}\text { Total } \\
\text { aircraft type }\end{array}$ \\
\hline Flight hours & & & $\begin{array}{c}\text { Total } \cdot \text { aircraft } \\
\text { type }\end{array}$ & $\begin{array}{c}\text { Total } \\
\text { aircraft type }\end{array}$ \\
\hline
\end{tabular}

(Source: Romano et al., 1999)

Those methods applied the same input: fuel consumption, number of flights, and flight hours. NASA (1999) also reported that different assumption in executing calculation of aircraft emission. A comparison made between inventory methods and actual aircraft fleet fuel consumption data. Longer flight times, greater actual aircraft weight and performance deterioration effects for the in-service aircraft become some causes in the results of aircraft emission estimation. 
The annual fuel burn and emissions of $\mathrm{CO}_{2}, \mathrm{H}_{2} \mathrm{O}, \mathrm{NO}_{\mathrm{x}}$, and $\mathrm{SO}_{\mathrm{x}}$ increased by $2 \%$ to $3 \%$ for 2005 to 2011, however, annual CO and HC emissions decreased by $1.6 \%$ and $8.7 \%$, respectively because of improving combustion efficiency in recent aircraft. These results were presented by Wasiuk et al. (2016). He also indicated that the Asian fleet contributed to the climate more than other regions. Over $40 \%$ of the total global aircraft $\mathrm{CO}$ and $\mathrm{HC}$ emissions were released at ground level (Wasiuk et al., 2016). This means that almost $50 \%$ of the aircraft emission will contribute to the air quality of airport and surrounded area.

To cater to this problem, Airport Council International (ACI) released the Airport Carbon and Emissions Reporting Tool (ACERT, 2018). ACERT is a self-contained Excel spreadsheet that enables an airport operator to calculate its own greenhouse gas (GHG) emissions inventory. ACERT was initially funded in 2011 by Transport Canada and later in 2018 already released the 5.1 version.

\section{RESEARCH METHODOLOGY}

\subsection{Data Collection}

Data collection is conducted to get the supporting required data to analyze the problem. The supporting required data include:

i) Aircraft Movements

The data of the airplane movement in question is the flight volume that occurred at Juanda Airport within a certain period, whether domestic or international, including the aircraft flying distance.

ii) Aircraft Specifications

The aircraft specification data includes the type of aircraft operated, the type of aircraft engine, the aircraft weight data and the aircraft fuel consumption.

iii) Emission Data

Emission data includes the gas content obtained from the literature study, in the form of test results of emission samples on the corresponding aircraft engine type. It also includes the emission factor data of each test substance. Data emission is extracted from the emission database of each engine type (ICAO, 2004)

iv) Meteorological data

The meteorological data in question is local meteorological data, which includes: moisture data, air pressure, temperature, wind direction, and magnitude. The data is aimed to determine the variables that may affect emission gas behavior when exiting the engine.

v) Data of route for take-off and landing

\subsection{Data Analysis and Calculation}

The supporting data of the studies that have been obtained are then analyzed. The steps taken are as follows:

i) Analyze flight data and aircraft movement. This stage covers the type of aircraft operating in Juanda, flight distance and intensity.

ii) Analyze the technical contribution of each type of aircraft per unit to carbon emissions by linking emission loads, aircraft specifications and fuel consumption as well as thrust.

iii) Analyze the distribution of emission through the flight path. 


\section{DATA ANALYSIS}

In order to know the contribution of each type of aircraft to the Juanda Airport carbon emission, firstly need to know the type of aircraft operating in Juanda and its specifications. Because emissions are closely related to fuel, in terms of both types and quantities, the engine specifications are necessary to determine the performance of aircraft fuel combustion resulting in carbon emissions.

Furthermore, the data required maximum flight distance, minimum and the average traveled by each type of aircraft. Flight distance data is required because not all aircraft operating in Juanda are always airing in a fully loaded condition, so flight data is required to estimate the amount of fuel used by each aircraft. In addition, this flight distance will be used to determine the operational weight of the aircraft through the payload graph.

Then, thrust plane analysis can be performed. Thrust analysis is needed to determine the amount of fuel used when the aircraft airborne in the Flight Safety Operation Area Imaginary Surface, which is the Juanda Airport air space. Based on the result of thrust analysis that produces real fuel consumption and emission factor of each aircraft, it can be calculated emission load by each type of aircraft by multiplying the total of real fuel consumption by emission factor and pollutant load. The pollutant load in the combustion of gasoline jet fuel in $\mathrm{kg} \cdot \mathrm{h}^{-1}$ can be seen in Table 2. The following loads are obtained for $\mathrm{HC}, \mathrm{CO}$ and $\mathrm{CO}_{2}$ values for each aircraft type. The process of obtaining the emission value is combining data from the aircraft type, the engine used for the particular aircraft and data emission of the engine.

The pollutant load is then distributed following the contour of aircraft movement. The aircraft movement has phases as shown in Fig. 1 that presents the process of aircraft from take off until landing. Each phase has its own flight level, which one produces different pollutant concentration. This concentration depends on the thrust of the aircraft. Each flight level enter different pressure and temperature of atmosphere that influence the distribution of pollutant

The flight path based on the flight level is accompanied by a flight path based on the direction of the aircraft route as presented in Fig. 2 and Fig. 3.

Table 2. Pollutant load $\left(\mathrm{kg} \cdot \mathrm{h}^{-1}\right)$.

\begin{tabular}{|l|l|l|c|c|c|}
\hline \multirow{2}{*}{ AIRCRAFT } & \multirow{2}{*}{ ENGINE } & \multirow{2}{*}{ TYPE } & \multicolumn{3}{|c|}{ EMISSION LOAD $\left(\mathrm{kg} \cdot \mathrm{h}^{-1}\right)$} \\
\cline { 4 - 6 } & & & $\mathrm{CO}$ & $\mathrm{HC}-$ & $\mathrm{CO}_{2}$ \\
\hline A-320 & CFM56 & Twin Engine Turbofan & 1.36 & 1.1 & 12,655 \\
\hline ATR-72 & PW127 F/M & Twin Engine Turboprop & 1.63 & 0.13 & 3,084 \\
\hline B-733 & CFM56-3 & Twin Engine Turbofan & 1.36 & 1.1 & 12,655 \\
\hline B-734 & CFM56-3 & Twin Engine Turbofan & 1.36 & 1.1 & 12,655 \\
\hline B-735 & CFM56-3 & Twin Engine Turbofan & 1.36 & 1.1 & 12,655 \\
\hline B-738 & CFM56-7 & Twin Engine Turbofan & 1.36 & 1.1 & 12,655 \\
\hline B-739 & CFM56-7 & Twin Engine Turbofan & 1.36 & 1.1 & 12,655 \\
\hline B-747-400 & CF6-80C2B1 & Twin Engine Turbofan & 1.36 & 1.1 & 12,655 \\
\hline
\end{tabular}

Fig. 2 pictures the four directions of aircraft movement from Juanda International Airport. The four routes determine the area of pollutant distribution. Fig. 2 is the aircraft route from Runway 10. The picture of Runway 28 is presented in Fig. 3. The aircraft route is determined for each airport (JEPPESEN, 2008). From Fig. 2 and Fig. 3 can be estimated the distance of each route to the urban area. The calculation example of determining distance used B-737-200 (B-737 Original) aircraft. 


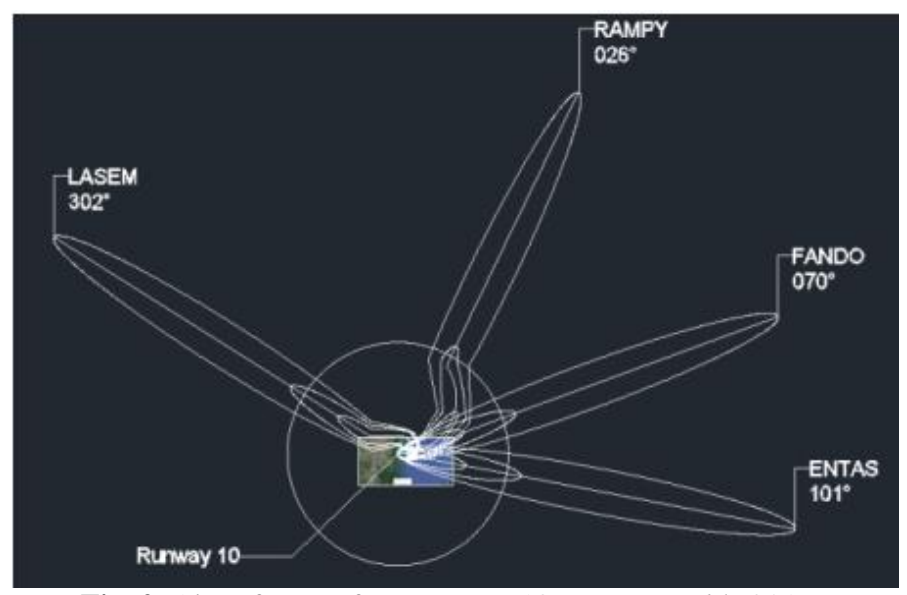

Fig. 2. Aircraft route from runway 10 (Source: Edik, 2017).

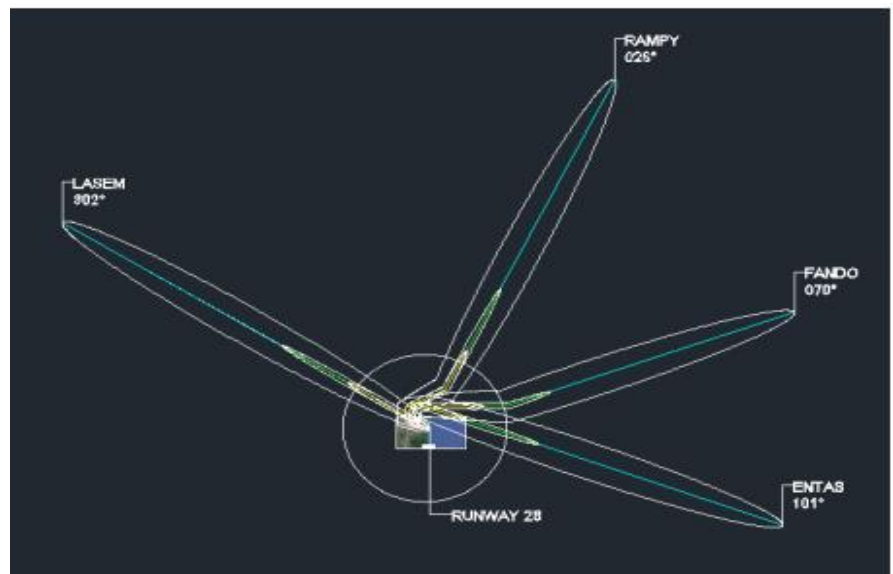

Fig. 3. Aircraft Route from Runway 28 (Source: Edik, 2017).

Table 3. Calculation of aircraft flight path.

\begin{tabular}{|c|c|c|c|c|}
\hline Session & ROC $(\mathrm{km} / \mathrm{h})$ & Time $(\min )$ & IAS $(\mathrm{knot})$ & Distance $(\mathrm{km})$ \\
\hline 1 & 27.43 & 3.33 & 175 & 18 \\
\hline 2 (FL150) & 21.95 & 8.33 & 250 & 64 \\
\hline 3 (FL240) & 18.29 & 9 & 250 & 69 \\
\hline 4 (Mach) & 9.14 & 26 & 0.68 & 363 \\
\hline 5 & 14.63 & 16.25 & 0.7 & 234 \\
\hline 6 & 64.01 & 4 & 250 & 30 \\
\hline
\end{tabular}

Table 3 is the calculation process of the flight path that was presented in Fig. 1. Session 1 to session 3 indicates the process of takeoff. Session 4 to session 6 is the descent process to the destination airport. The Distance for Session 1 to session 3 is calculated from the airport origin, session 4 to session 6 is calculated from the destination airport. The calculation of the flight path is aimed to demonstrate that the climbing process of the aircraft will occur on the city center of Surabaya. This can be seen that session 1 occurs up to $18 \mathrm{~km}$ from the airport. 
From the analysis of distance, can be derived that the distance of airport to city center is equal to the position of aircraft at session 1 during the climb to $5000 \mathrm{ft}(1.5 \mathrm{~km})$. This distance produces pollutant based on the fuel consumption and thrust of the aircraft. At this position, the emission is high due to the climbing process.

The emission is produced by estimating the flight duration at the distance from the city. This flight duration is then multiplied to the emission load as presented in Table 2 . The distance from the city is important since it may affect the quality of life of the people. The consideration idea is similar to the process in selecting a location for waste landfill (Mănoiu et al., 2013). Unlike landfill, air pollution may be affected by the wind that will require analysis in spatial distribution (Croitoru et al., 2011). This issue will be included in the next study.

\section{CONTROL MEASURES OF AIRCRAFT MOVEMENT}

Aircraft emission control has been carried out by international agencies. The efforts of the International Air Transport Association (IATA) implement four pillars of strategies to reduce emissions:

i) Investment in technology

Advances in aircraft technology with the Technology Roadmap identify the future aircraft technology that can reduce emissions $20 \%$ to $35 \%$ per aircraft. In addition, using biofuel fuel can reduce airplane $\mathrm{CO}_{2}$ emissions by $80 \%$. This gives an overview of the planes, engines and technology systems can help reduce fuel and carbon emissions.

ii) Effective operation

Operational improvements, including reducing the use of the Auxiliary Power Unit (APU), more efficient flight procedures, and airplane weight reduction measures can reduce aircraft emissions by $3 \%$ by 2020 .

iii) Infrastructure efficient

Air Traffic Management (ATM) and a good airport infrastructure can provide an additional $4 \%$ reduction in emissions by 2020 .

iv) Positive economic instruments

Economic measures that can be done is with cost savings.

The four pillars strategy is adopted by the global aviation industry as well as ICAO member countries. Since 2007 IATA has made significant progress. Aviation emissions fell from $671000000 \mathrm{t}$ of $\mathrm{CO}_{2}$ in 2007 and declined to $666000000 \mathrm{t}$ of $\mathrm{CO}_{2}$ in 2008.

In addition to international agencies, there are many studies that parse aircraft emission control. As Gonzalez \& Hosoda (2016) observed the impact of commercial aviation growth on $\mathrm{CO}_{2}$ emissions, as well as the potential impacts of climate change. Fuel tax stipulation can reduce aircraft $\mathrm{CO}_{2}$ emissions.

Grampella et al. (2016) disclose that the costs that affect air pollution and plane noise are primarily from the age of the aircraft. Therefore, there is a need to control the designer in making the flight sustainable and environmentally friendly. Noise control can also be applied with airport development in the offshore area, the cost effects and risks resulting in fewer and more profitable for urban development (Yan et al., 2013).

In Indonesia, there are regulations to control the impact of aircraft movement on the environment. The regulation regulates the construction and operation of more environmentally friendly airports. The Regulation set forth in the Law of the Republic of Indonesia Number I Year 2009 on Aviation and more specifically in the Regulation of the 
Director General of Civil Aviation Number: SKEP 124/VI/2009 on Guidelines for Implementation of Eco-Friendly Airport (Eco Airport), 2009.

\section{CONCLUSION}

The parties of the aviation organization may make regulations for its members to reduce the high number of emissions. For the airport, managers can manage a good airport infrastructure to manage airport operations more efficiently. While the government can support sustainable aviation and environmentally friendly by implementing policies. Such as the emissions tax policy, the development of airports in the offshore area and the regulation on the eco airport. For aircraft production, the contribution of the reduction of the impact of aircraft movement on the environment can be done by applying environmentally friendly aircraft technology, which is the fuel-efficient and low noise level

\section{REFERENCES}

ACERT (2018) Airport Carbon and Emissions Reporting Tool (ACERT), Airports Council International. Available from http://www.aci.aero/About-ACI/Priorities/Environment/ACERT [Accessed March 2019]

Croitoru, A., Holobâcân, I., Rus, I. \& Mureşan, T. (2011) Multivariate statistical analysis of fog phenomenon in Northwestern Romania. Geographia Technica 6 (2): 9-19

EASA (2015) ICAO Aircraft Engine Emissions Databank, EASA. Available from https://www.easa.europa.eu/easa-and-you/environment/icao-aircraft-engine-emissionsdatabank. [Accessed March 2019]

Edik, D.Y. (2017), Studi penentuan lokasi runway 2 dengan memperhatikan kontur kebisingan Bandara Juanda, Undergraduate Thesis, Department of Civil Engineering, Institut Teknologi Sepuluh Nopember (Unpublished).

Eurocontrol (2016) Aircraft Performance Database, Eurocontrol. Available from https://contentzone.eurocontrol.int/aircraftperformance/details.aspx?ICAO=B738\&GroupFilter $=4$. [Accessed March 2019]

FAA (2017). - Noise Standards: AC no: 36-4d Type and Airworthiness Certification, FAA. Available from https://www.faa.gov/documentLibrary/media/Advisory_Circular/AC_36-4D.pdf.

[Accessed March 2019]

Gonzalez, R. \& Hosoda, E. B. (2016) Environmental Impact of Aircraft Emissions and Aviation Fuel Tax in Japan. Journal of Air Transport Management, 57, 234-240.

Grampella, M., Martini, G., Scotti, D. \& Zambon, G. (2016) The Factors Affecting Pollution and Noise Environmental Costs of The Current Aircraft Fleet: An Econometric Analysis. Transportation Research Part A: Policy and Practice, 92: 310-325.

ICAO (2004) Noise Certification Workshop - Annex 16 Environmental Protection, Volume II: Aircraft Engine Emissions, International Civil Aviation Organization, Canada. Available from https://www.icao.int/Meetings/EnvironmentalWorkshops/Documents/NoiseCertificationWorks hop-2004/BIP_2_2_jb.pdf. [Accessed March 2019]

JEPPESEN (2008) Airport Information WARR JUANDA. Available from http://www.flysea.com/charts/WARR.pdf. [Accessed March 2019]

Mănoiu, V., Fontanine, I \& Costache, R (2013) Using GIS techniques for assessing waste landfill placement suitability. Case study: Prahova County, Romania. Geographia Technica, 8(2), $47-$ 56.

Masiol, M. \& Harrison R. M. (2015) Quantification of Air Quality Impacts of London Heathrow Airport (UK) from 2005 to 2012. Atmospheric Environment, 116, 308-319. 
NASA (1999). An Evaluation of Aircraft Emissions Inventory Methodology by Comparisons With Reported Airline Data, National Aeronautics and Space Administration. Available from https://ntrs.nasa.gov/archive/nasa/casi.ntrs.nasa.gov/19990092373.pdf. [Accessed March 2019]

Rissman, J., Arunachalam S., BenDor T. \& West J. J. (2013) Equity and Health Impacts of Aircraft Emissions at The Hartsfield-Jackson Atlanta International Airport. Landscape Urban Planning, $120,234-247$

Romano, D., Gaudioso, D. \& De Lauretis, R. (1999) Aircraft Emissions: A Comparison of Methodologies Based On Different Data Availability. Environmental Monitoring and Assessment, 56(1), 51-74

Rypdal, K. (2002) Aircraft Emission, Background Papers IPCC Expert Meetings on Good Practice Guidance and Uncertainty Management in National Greenhouse Gas Inventories. Available from https://www.ipcc-nggip.iges.or.jp/public/gp/bgp/2_5_Aircraft.pdf. [Accessed March 2019]

Song, S. K. \& Shon, Z. H. (2012) Emissions of Greenhouse Gases and Air Pollutants from Commercial Aircraft at International Airports in Korea. Atmospheric Environment, 61, 148-158

Wasiuk, D. K., Khan, Md A. H., Shallcross, D. E. \& Lowenberg, M. H. (2016) A Commercial Aircraft Fuel Burn and Emissions Inventory for 2005-2011. Atmosphere, 7(6): 78.

Yan, H. K., Wang, N., Wei, L. \& Fu, Q. (2013) Comparing Aircraft Noise Pollution and Cost-Risk Effects of Inland and Offshore Airports: The Case of Dalian International Airport, Dalian, China. Transport Research Part D: Transport and Environment, 24: 37-43. 